JPDN ISSN 2579-6461 (Online) ISSN 2460-6324 (Print)

Jurnal Pendidikan Dasar Nusantara Volume 5 | Nomor 2 | Januari 2020 |

DOI:https://doi.org/10.29407/jpdn.v5i2.13952

\title{
PENGEMBANGAN PERANGKAT PEMBELAJARAN BERBASIS STEM (SCIENCE, TECHNOLOGY, ENGINEERING, AND MATHEMATICS) UNTUK MAHASISWA PRODI PGSD
}

\author{
Ifa Seftia Rakhma Widiyanti ${ }^{1}$, Saeful Mizan ${ }^{2}$ \\ ifaseftia@gmail.com ${ }^{1}$, miz_zhan@yahoo.com ${ }^{2}$ \\ PGSD, FKIP, Universitas PGRI Ronggolawe Tuban ${ }^{1,2}$ \\ No Handphone:+6285640380916, +628563355944
}

\begin{abstract}
Abstrak: Penelitian ini bertujuan untuk menemukan bentuk perangkat pembelajaran berbasis STEM (Science, Technology, Engineering, and Mathematics) dengan tujuan khusus menguji kevalidan, keefektifan, dan kepraktisan perangkat pembelajaran berbasis STEM yang dikembangkan. Penelitian pengembangan ini menggunakan desain Research \& Development yang disederhanakan ke dalam dua tahapan, yaitu tahap pendahuluan dan tahap pengembangan. Penelitian pengembangan ini menghasilkan perangkat dalam bentuk Rencana Pelaksanaan Pembelajaran (RPP) berbasis STEM, Lembar Kerja Mahasiswa (LKM) berbasis STEM, bahan ajar berbasis STEM, lembar Alat Penilaian Kemampuan Mengajar (APKM) 1 dan 2, lembar observasi aktivitas mahasiswa selama pembelajaran berbasis STEM, lembar angket minat mahasiswa terhadap pembelajaran berbasis STEM. Perangkat penilaian yang dikembangkan memiliki validitas sangat tinggi dengan skor 84,38 \% untuk aspek kesesuaian isi, 82,50\% untuk aspek kebahasaan, dan $82,14 \%$. untuk aspek kegrafikan. Perangkat pembelajaran yang dikembangkan efektif digunakan oleh mahasiswa dan dosen pada materi pesawat sederhana karena dapat digunakan untuk mendeskripsikan profil STEM mahasiswa uji coba. Setelah melaksanakan pembelajaran berbasis STEM, kemampuan Science mahasiswa meningkat sebesar 27,20\%, kemampuan technology meningkat sebesar 23,36\%, kemampuan engineering meningkat sebesar 55,20 \%, dan kemampuan mathematics meningkat sebesar 81,80\%. Keefektifan pembelajaran juga ditunjukkan dengan keberhasilan dosen mendisain pembelajaran. Disain pembelajaran memperoleh skor 100 dari kedua penilai. Perangkat pembelajaran yang dikembangkan praktis digunakan oleh mahasiswa dan dosen untuk materi pesawat sederhana berdasarkan respon positif mahasiswa dan dosen uji coba. Kepraktisan perangkat pembelajaran berbasis STEM ditunjukkan dari keterlaksanaan pembelajaran. Persentase aktivitas mahasiswa saat pembelajaran STEM sebesar 75,79\% menunjukkan aktivitas mahasiswa saat pembelajaran termasuk kategori baik dan kemampuan mengajar dosen memperoleh skor rata-rata 97,73.
\end{abstract}

Kata kunci: Pembelajaran, Science, Technology, Engineering, Mathematics 


\title{
Ifa, Saeful. Pengembangan Perangkat Pembelajaran STEM \\ DEVELOPMENT OF STEM (SCIENCE, TECHNOLOGY, ENGINEERING, AND MATHEMATICS) STUDY INSTRUMENT FOR ELEMENTARY TEACHER EDUCATION STUDENTS
}

\begin{abstract}
The general objective of this study was to find a kind of Science, Technology, Engineering, and Mathematics (STEM) study instruments, and the specific purposes of this study were to investigate the validity, effectiveness, and practicality of it. This was a Research \& Development study which was simplified into two stages; they are the preliminary stage and the development stage. This study resulted several kinds of instruments: lesson plan, worksheets, material lesson, teaching evaluation sheets, observation sheets, and questionares. The validity was very good with score $84,38 \%$ for content aspect, $82,50 \%$ for language aspect, and 82,14 \% for display aspect. The instruments were very effective to be used by elementary teacher education students and lecturers in the simple machines material to describe the STEM profile's teacher education students. The instruments could practically be used by the elementary teacher education students and lecturers for the simple machines material based on the positive elementary teacher education students and lecturers responses. Students' science ability increased $27.20 \%$, technology ability increased $23.36 \%$, engineering ability increased $55.20 \%$, and mathematics ability increased $81.80 \%$. The effectiveness of learned was shown by the success of the lecturer in designed learning. The learning design got score of 100 from both expert. The developed learning device is practically used by students and lecturers for simple machines material based on positive responses of students and lecturer. The practicality of learning tools based STEM is shown from the implementation of learning. The percentage of student activities during STEM learning was $75.79 \%$, it showed that student activities during learning including the good category and the teaching ability of lecturers got average score 97,73.
\end{abstract}

Keywords: Learning, Science, Technology, Engineering, Mathematics

\section{PENDAHULUAN}

Keterampilan abad ke-21 merupakan salah satu topik yang sering dibahas akhirakhir ini. Salah satu ciri yang paling menonjol pada abad 21 adalah semakin bertautnya dunia ilmu pengetahuan, sehingga sinergi di antaranya menjadi semakin cepat (Hidayah, dkk, 2017: 127). Paradigma pendidikan nasional abad 21 dapat dirumuskan sebagai berikut, (1) untuk menghadapi abad 21 yang makin syarat dengan teknologi dan sains dalam masyarakat global, maka pendidikan kita haruslah berorientasi pada ilmu pengetahuan matematika dan sains alam disertai dengan sains sosial dan kemanusiaan dengan keseimbangan yang wajar; (2) Pendidikan ilmu pengetahuan bukan hanya membuat seorang mahasiswa berpengetahuan, melainkan juga menganut sikap keilmuan, yaitu kritis, logis, analitis dan kreatif, namun disertai pula dengan kemampuan 
Ifa, Saeful. Pengembangan Perangkat Pembelajaran STEM

beradaptasi. (3) Pada setiap jenjang pendidikan perlu ditanamkan jiwa kemandirian, karena kemandirian pribadi mendasari kemandirian bangsa, kemandirian dalam melakukan kerjasama yang saling menghargai dan menghormati (BSNP, 2010).

Dalam abad ini masing-masing ilmu tidak lagi harus bekerja sendiri, melainkan berbagai cabang ilmu dapat bekerja sama, bukan hanya dalam sesama kelompok sains, teknologi atau sains sosial dan humaniora saja, melainkan dalam banyak hal antara beberapa kelompok (Khoiriyah, dkk. 2018). Sejalan dengan hal tersebut, paradigma pembelajaran abad 21 menekankan pada kemampuan mahasiswa dalam mencari tahu dari berbagai sumber, merumuskan permasalahan, berfikir analitis dan kerjasama serta berkolaborasi dalam menyelesaikan masalah yang sering disebut keterampilan abad 21

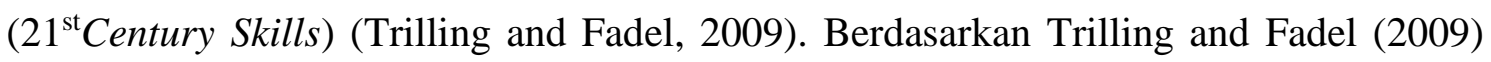
secara umum keterampilan abad 21 terbagi kepada tiga keterampilan, yaitu Learning and Innovation Skills (Keterampilan Belajar dan Berinovasi), Information, Media, and Technology Skills (Keterampilan Teknologi dan Media Informasi) dan Life and Career Skills (Keterampilan Hidup dan Berkarir).

Salah satu pembelajaran yang dapat mengintegrasikan $21{ }^{\text {st }}$ Century Skills yaitu STEM (Science, Technology, Engineering, and Mathematics) (Utami, dkk., 2017). STEM adalah pendekatan dalam pendidikan di mana Sains, Teknologi, Teknik, Matematika terintegrasi dengan proses pendidikan berfokus pada pemecahan masalah dalam kehidupan sehari-hari yang nyata serta dalam kehidupan professional (Winarni, dkk., 2016). STEM menunjukkan kepada mahasiswa bagaimana konsep, prinsip, teknik sains, teknologi, teknik dan matematika (STEM) digunakan secara terintegrasi untuk mengembangkan produk, proses, dan sistem yang bermanfaat bagi kehidupan manusia (Ostler, 2012).

Penggunaan pendekatan STEM dalam bidang pendidikan memiliki tujuan untuk mempersiapkan mahasiswa agar dapat bersaing dan siap untuk bekerja sesuai bidang yang ditekuninya. STEM memberi pendidik peluang untuk menunjukkan kepada mahasiswa bahwa konsep, prinsip, dan teknik dari STEM digunakan secara terintegrasi dalam pengembangan produk, proses, dan sistem yang digunakan dalam kehidupan sehari-hari mereka. Oleh karena itu, definisi STEM diadopsi sebagai pendekatan interdisiplin pada pembelajaran (Reeve, 2013). Dalam pembelajaran berbasis STEM mahasiswa menggunakan sains, teknologi, rekayasa, dan matematika dalam konteks 
Ifa, Saeful. Pengembangan Perangkat Pembelajaran STEM

nyata yang menghubungkan sekolah, dunia kerja, dan dunia global guna mengembangkan literasi STEM yang memungkinkan mahasiswa mampu bersaing dalam abad ke-21 (Thibaut, et al., 2018).

Berdasarkan survei yang dilakukan, pembelajaran di Prodi PGSD UNIROW belum ada yang menggunakan pembelajaran berbasis STEM. Berdasarkan hasil survei tersebut, maka perlu adanya pembelajaran yang dapat mempersiapkan mahasiswa dalam menghadapi tantangan Abad 21. Salah satu cara yang dapat dilakukan dalam memperbaiki kualitas pendidikan khususnya di prodi PGSD UNIROW melalui pembelajaran berbasis STEM. Pembelajaran berbasis STEM yang dilakukan dalam penelitian menggunakan pola Embedded/ tertanam. Metode pola pendekatan tertanam umumnya dikenal luas sebagai pendekatan yang memberikan penekanan pada pengetahuan yang didapatkan melalui kajian permasalahan di dunia nyata dan teknik pemecahan masalah dalam konteks sosial, budaya, dan fungsional. Dalam pendekatan tertanam, terdapat satu materi yang lebih diutamakan dibandingkan yang lainnya sehingga integritas dari subjek yang diutamakan tetap terjaga. Pola pendekatan tertanam meningkatkan pembelajaran dengan menunjukan hubungan yang jelas antara materi yang diutamakan dan materi pendampingnya. Hubungan ini disampaikan secara kontekstual dalam penjelasan bahwa materi-materi pendamping adalah penguat konsep pada materi utama (Ntemngwa, 2018).

Pembelajaran STEM yang dilakukan pada mahasiswa semester 2 dengan asumsi seluruh mahasiswa telah melalui mata kuliah konsep IPA di SD, dan konsep Matematika di SD. Melalui ketiga mata kuliah di Prodi PGSD tersebut maka sains dan teknologi diintegrasikan dalam mata kuliah konsep IPA di SD, rekayasa diintegrasikan dalam mata kuliah pendidikan IPA di SD dan matematika diintegrasikan dalam mata kuliah konsep Matematika di SD.

Berdasarkan latar belakang maka peneliti melakukan penelitian Pengembangan Perangkat Pembelajaran STEM (Science, Technology, Engineering, and Mathematics) untuk Mahasiswa Prodi PGSD UNIROW untuk mengetahui 1) implementasi pembelajaran STEM (Science, Technology, Engineering, and Mathematics) pada mahasiswa Prodi PGSD UNIROW, dan 2) peningkatan kemampuan 21th century skills mahasiswa Prodi PGSD UNIROW dengan pembelajaran STEM. 


\section{Ifa, Saeful. Pengembangan Perangkat Pembelajaran STEM}

\section{METODE}

Penelitian pengembangan ini menggunakan desain penelitian Research \& Development (R\&D) yang dikembangkan Sugiyono (2010) dan telah disederhanakan ke dalam dua tahapan, yaitu tahap pendahuluan dan tahap pengembangan. Tahap pendahuluan melalui proses kajian pustaka, deskripsi dan analisis temuan (model faktual). Tahap pengembangan meliputi tahap desain produk awal (produk hipotetik), uji ahli, analisis hasil validasi ahli dan revisi, uji coba skala terbatas, revisi, tahap uji coba penelitian skala luas, analisis dan penyempurnaan, dan akhirnya diperoleh produk final.

Validasi ahli diperoleh dengan memberikan lembar validasi kepada validator sebelum uji skala terbatas yang dipilih sebagai responden. Lembar validasi yang digunakan bertujuan untuk mengetahui pendapat dan tingkat kevalidan perangkat pembelajaran berbasis STEM. Kevalidan perangkat penilaian literasi sains yang telah disusun, diperoleh peneliti menggunakan hasil validitas isi dan validitas konstruk. Validitas isi diperoleh dari kesesuaian antara perangkat pembelajaran berbasis STEM yang dikembangkan dengan SK, Indikator, dan materi kuliah yang dipelajari mahasiswa. Validitas konstruk diperoleh dari pendapat para ahli tentang tujuan perangkat pembelajaran berbasis STEM yang dikembangkan.

Soal-soal tes untuk mengevaluasi kemampuan STEM dan $21{ }^{\text {st }}$ Century Skills mahasiswa terhadap materi pesawat sederhana disajikan dalam bentuk pretest, LKM, dan postest. Deskripsi kemampuan STEM dan $21^{\text {st }}$ Century Skills mahasiswa menunjukkan keefektifan perangkat pembelajaran yang dikembangkan. Keefektifan perangkat pembelajaran berbasis STEM juga ditunjukkan dengan keberhasilan pelaksanaan pembelajaran. Indikator keberhasilan pembelajaran diperoleh dari hasil penilaian ahli terhadap disain pembelajaran dan aktivitas mahasiswa saat pembeajaran berbasis STEM.

Kepraktisan produk ditentukan dari data angket minat mahasiswa dan respon dosen terhadap perangkat pembelajaran yang dikembangkan. Angket respon dosen diberikan kepada dosen pengampu mata kuliah konsep IPA di SD, konsep Matematika di SD, dan pendidikan IPA.

\section{HASIL}

Pada penelitian yang berjudul Implementasi Pembelajaran STEM (Science, Technology, Engineering, and Mathematics) pada Mahasiswa Prodi PGSD UNIROW 
Ifa, Saeful. Pengembangan Perangkat Pembelajaran STEM

untuk Meningkatkan $21^{\text {th }}$ Century Skills yang telah dilakukan diperoleh data berupa: (1) hasil validasi ahli, (2) data uji coba lapangan. Berikut ini penjabaran terkait data yang diperoleh dari penelitian.

\section{Hasil Validasi Ahli}

Produk berupa perangkat pembelajaran dan bahan ajar berbasis STEM yang telah dikembangkan selanjutnya divalidasikan kepada dua validator yaitu: Prof. Dr. Supiana Dian Nurtjahyani, M. Kes. dan Ir. Hernik Pujiastuti, M. Pd. Aspek yang dinilai oleh kedua validator meliputi kesesuaian isi, kebahasaan, dan komponen kegrafikan. Aspek kesesuaian isi memiliki delapan indikator penilaian, aspek kebahasaan memiliki lima indikator penilaian, aspek komponen kegrafikan memiliki tujuh indikator penilaian. Berikut data hasil validasi dari ketiga validator:

\section{Aspek Kesesuaian Isi}

Data yang diperoleh dari hasil validasi pada aspek kesesuaian isi disajikan pada Gambar 1.

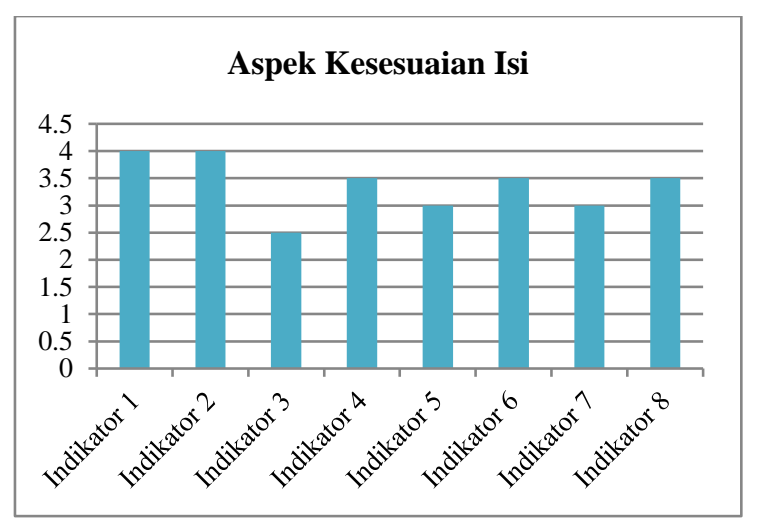

Gambar 1. Grafik Hasil Validasi Aspek Kesesuaian Isi

Berdasarkan data yang disajikan dalam Gambar 1, indikator 1 dan 2 memperoleh skor maksimal dari validator. Skor terendah diperoleh pada indikator 3 yaitu kejelasan setiap komponen pada perangkat pembelajaran berbasis STEM. Kejelasan pada Lembar Kerja Mahasiswa dan bagan STEM dinilai kurang oleh validator. Saran dari validator, peneliti seharusnya memberikan petunjuk yang jelas untuk mengerjakan Lembar Kerja Mahasiswa dan bagan STEM sehingga mahasiswa tidak kesulitan saat menggunakan LKM dan mengerjakan bagan STEM. Aspek kesesuaian isi memperoleh presentase sebesar 84, $38 \%$ dengan kriteria baik sekali.

\section{Aspek Kebahasaan}


Ifa, Saeful. Pengembangan Perangkat Pembelajaran STEM

Data yang diperoleh dari hasil validasi pada aspek kebahasaan ditunjukkan Gambar 2.

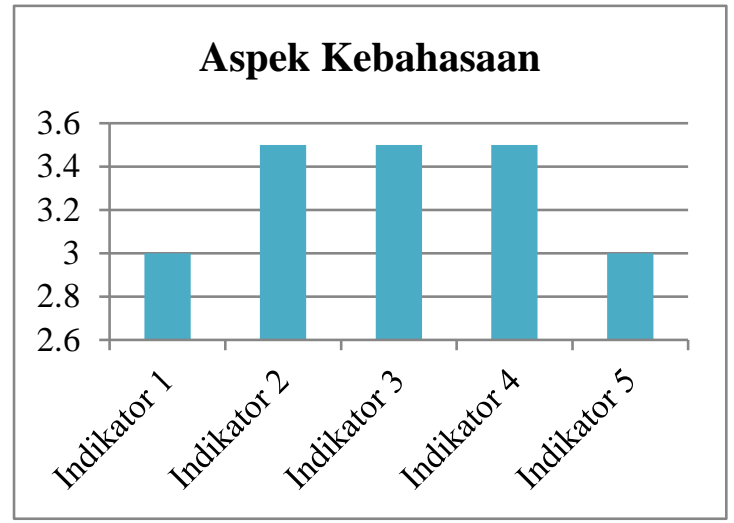

\section{Gambar 2. Grafik Hasil Validasi Aspek Kebahasaan}

Validator memberikan rata-rata skor 3,5 untuk indikator 2, 3, dan 4 pada aspek kebahasaan. Indikator 1 dan 5 memperoleh skor 3. Perangkat pembelajaran yang akan digunakan oleh dosen, validator, observer, dan mahasiswa telah memenuhi aspek kebahasaan antara lain, kalimat di dalam perangkat pembelajaran mudah dipahami, sesuai dengan kaidah bahasa Indonesia yang baik dan benar, komunikatif, dan sesuai dengana tingkat intelektual mahasiswa. Aspek kesesuaian isi memperoleh presentase sebesar 82, $50 \%$ dengan kriteria baik sekali.

\section{Aspek Komponen Kegrafikan}

Data yang diperoleh dari hasil validasi pada aspek komponen kegrafikan disajikan Gambar 3.

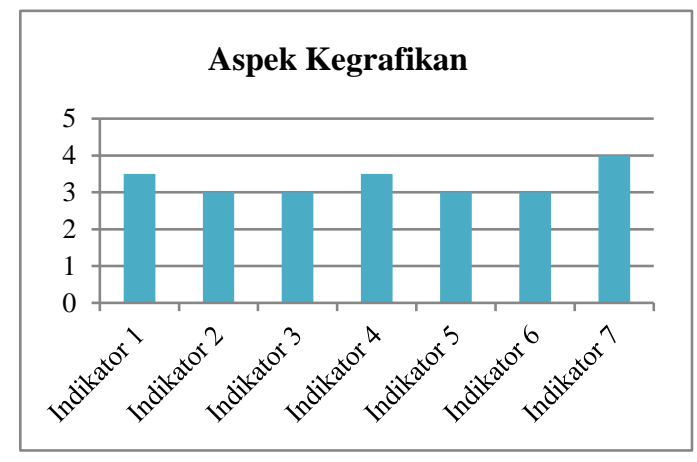

\section{Gambar 3. Grafik Hasil Validasi Aspek Kegrafikan}

Aspek kegrafikan disajikan pada lembar validasi supaya perangkat pembelajaran yang digunakan mahasiswa lebih menarik. Terdapat tujuh (7) indikator pada aspek 


\section{Ifa, Saeful. Pengembangan Perangkat Pembelajaran STEM}

kegrafikan. Indikator 7, yaitu ketersedian ruang untuk menulis dan menggambar pada perangkat perangkat pembelajaran berbasis STEM diapresiasi oleh validator. Ruang menulis dan menggambar dapat digunakan mahasiswa untuk mengembangkan kreatifitas dan keterampilan komunikasi mahasiswa dalam bentuk tulisan. Skor 3,5 diperoleh pada aspek 1 dan 4, yaitu kesesuaian pemilihan huruf/ angka pada perangkat pembelajaran dan kemenarikan gambar dalam LKM. Indikator 2, 3, 5, dan 6 memperoleh skor 3. Aspek kegrafikan memperoleh presentase sebesar 82, 14 \% dengan kriteria baik sekali.

Berdasarkan rekapitulasi hasil validasi maka dapat diketahui bahwa semua aspek penilaian mendapatkan kriteria sangat baik. Aspek yang mendapatkan persentase skor tertinggi adalah aspek kesesuaian isi dengan persentase skor sebesar 84, $38 \%$. Sedangkan aspek yang mendapatkan persentase skor terendah adalah aspek kegrafikan dengan persentase skor sebesar 82, $14 \%$. Aspek kebahasaan mendapatkan persentase skor sebesar 82, $50 \%$. Berdasarkan penilaian tersebut maka aspek yang memerlukan perbaikan lebih banyak adalah aspek kegrafikan, yaitu pada aspek pemilihan warna LKM dan bahan ajar.

\section{Hasil Uji Coba Lapangan}

Setelah dilakukan tahap validasi, maka tahap selanjutnya dilakukan uji coba lapangan. Uji coba lapangan dilakukan pada mahasiswa PGSD UNIROW rombel 2018 A dan 2018 C. Rombel 2018 A sebagai kelas eksperimen dan rombel 2018 C sebagai kelas kontrol. Data uji coba lapangan ditunjukkan sebagai berikut.

\section{Pretest}

Data hasil pretest kelas eksperimen berbasis STEM disajikan pada Gambar 4 
Ifa, Saeful. Pengembangan Perangkat Pembelajaran STEM

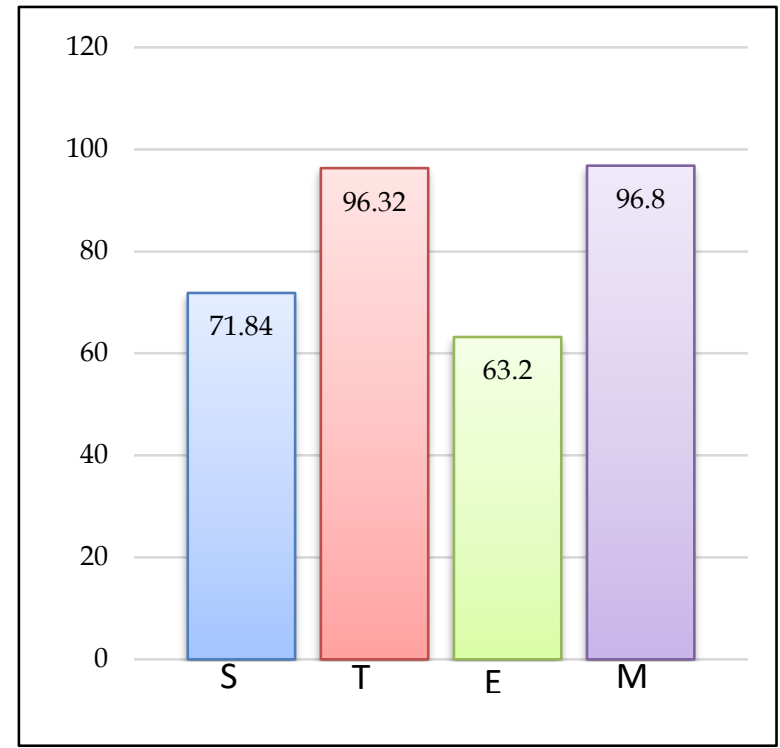

\section{Gambar 4. Grafik Hasil Pretest Kelas Eksperimen}

Berdasarkan Gambar 4 diketahui bahwa mahasiswa kelas eksperimen kesulitan menjawab semua soal pretest yang diberikan. Mahasiswa kelas eksperimen kesulitan merancang percobaan yang menerapkan prinsip bidang miring, menganalisis teknologi yang menerapkan prinsip bidang miring, dan melengkapi bagan STEM. Mahasiswa kelas eksperimen memahami kalimat pertanyaan pada lembar pretest, tetapi kesulitan untuk menjawabnya. Pertanyaan nomor empat (4) untuk melengkapi bagan STEM seharusnya diberi contoh sehingga mahasiswa kelas eksperimen memperoleh gambaran untuk melengkapi bagan STEM.

Data hasil pretest kelas kontrol berbasis STEM disajikan pada Gambar 5. 


\section{Ifa, Saeful. Pengembangan Perangkat Pembelajaran STEM}

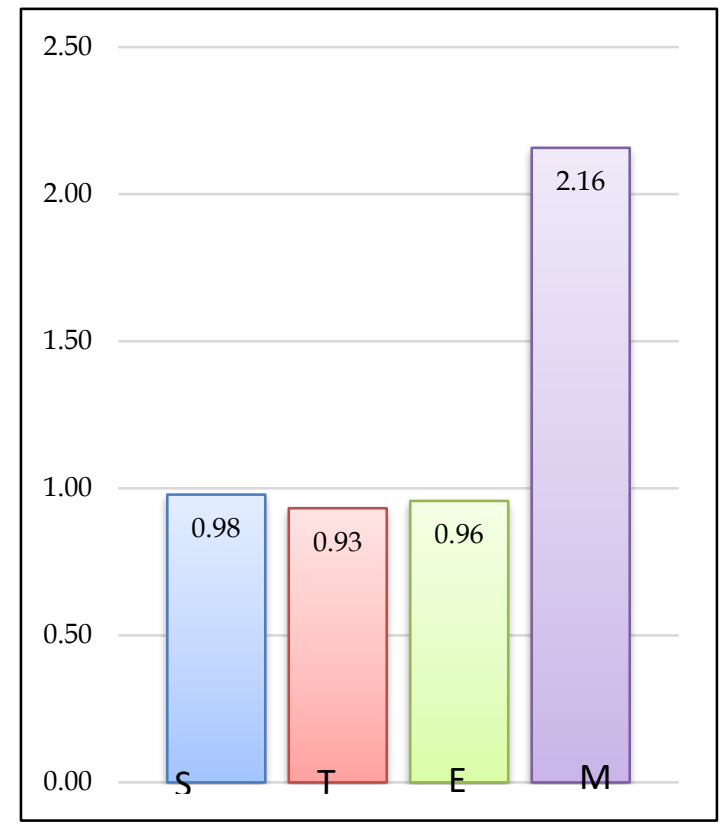

\section{Gambar 5. Grafik Hasil Pretest Kelas Kontrol}

Berdasarkan Gambar 5 diketahui bahwa mahasiswa kelas kontrol kesulitan menjawab semua soal pretest yang diberikan. Mahasiswa kelas kontrol kesulitan merancang percobaan yang menerapkan prinsip bidang miring, menganalisis teknologi yang menerapkan prinsip pesawat sederhana, dan melengkapi bagan STEM. Mahasiswa kelas kontrol memahami kalimat pertanyaan pada lembar pretest, tetapi kesulitan untuk menjawabnya. Pertanyaan nomor empat (4) untuk melengkapi bagan STEM seharusnya diberi contoh sehingga mahasiswa kelas kontrol memperoleh gambaran untuk melengkapi bagan STEM.

\section{Hasil Penilaian Kemampuan Pengajar}

Terdapat dua komponen penilaian kemampuan pengajar, yaitu antara lain penilaian disain pembelajaran STEM dan penilaian kemampuan mengajar disesuaikan dengan STEM.

Berdasarkan hasil analisis diperoleh data bahwa rata-rata disain pembelajaran memperoleh skor maksimal 64 dengan persentase sebesar $100 \%$. Persentase tersebut menunjukkan disain pembelajaran STEM sangat baik diterapkan pada pembelajaran mata kuliah pendidikan IPA materi pesawat sederhana. Disain pembelajaran STEM diharapkan mampu mengembangkan keterampilan abad 21 mahasiswa PGSD UNIROW. 


\section{Ifa, Saeful. Pengembangan Perangkat Pembelajaran STEM}

Selain penilaian disain pembelajaran STEM, pengamat juga menilai kemampuan pengajar yang disesuaikan dengan STEM. Lembar penilaian kemampuan pengajar yang disesuaikan dengan STEM. Data observasi menunjukkan bahwa pengajar kurang maksimal hanya pada indikator $2 \mathrm{~b}$ yaitu penggunaan media. Pengamat menilai media yang digunakan pengajar belum sesuai untuk mencapai kompetensi yang akan dicapai. Disain pembelajaran menunjukkan mahasiswa mampu mendesain alat yang menerapkan rekayasa teknologi dan engineering, tetapi pengajar masih menggunakan alat peraga pembelajaran yang belum menerapkan rekayasa teknologi dan engineering.

\section{Hasil Observasi Aktivitas Mahasiswa saat Pembelajaran STEM}

Aktivitas mahasiswa yang diamati saat pembelajaran STEM berlangsung dibedakan menjadi 4 aspek yaitu aspek Science, Technology, Engineering, dan Mathematics. Keempat aspek tersebut masing-masing dibedakan menjadi 2 indikator. Indikator masing-masing aspek disajikan pada Tabel 1.

Tabel 1. Tabel Kriteria Aspek Aktivitas Mahasiswa saat Pembelajaran STEM

\begin{tabular}{|c|l|}
\hline $\begin{array}{c}\text { Aspek yang } \\
\text { dinilai }\end{array}$ & \multicolumn{1}{c|}{ Indikator } \\
\hline Science & $\begin{array}{l}\text { 1. Menyebutkan lebih dari satu informasi terkait permasalahan yang } \\
\text { diberikan } \\
\text { 2. Menghubungkan informasi dengan dasar teori }\end{array}$ \\
\hline Technology & $\begin{array}{l}\text { 1. Memperkirakan solusi dari permasalahan yang diberikan. } \\
\text { 2. Mendesain alat-alat sederhana/teknologi dari solusi yang diberikan }\end{array}$ \\
\hline Engineering & $\begin{array}{l}\text { 1. Menyimpulkan dari teknologi atau alat yang telah tercipta } \\
\text { 2. Menggunakan teknologi atau alat yang telah tercipta }\end{array}$ \\
\hline Mathematics & $\begin{array}{l}\text { 1. Menghitung keuntungan dari penggunaan teknologi yang telah tercipta } \\
\text { 2. Menghitung kerugian dari tidak menggunakan teknologi yang telah } \\
\text { tercipta }\end{array}$ \\
\hline
\end{tabular}

Persentase aktivitas mahasiswa saat pembelajaran STEM sebesar 75,79 \% menunjukkan aktivitas mahasiswa saat pembelajaran termasuk kategori baik. Mahasiswa masih keulitan melengkapi bagan STEM pada pertemuan pertama penerapan pembelajaran berbasis STEM. Setelah diberi penjelasan dosen, mahasiswa bisa melekngkapi bagan STEM pada pertemuan selanjutnya meskipun belum maksimal hasilnya. Hanya terdapat dua mahasiswa yang mampu memenuhi indikator Technology yaitu mendesain alat-alat sederhana/ teknologi dari solusi yang diberikan. Setelah 
Ifa, Saeful. Pengembangan Perangkat Pembelajaran STEM

dilakukan wawancara, kedua mahasiswa tersebut memiliki background pendidikan kejuruan. Data tersebut menunjukkan mahasiswa masih kesulitan mendesain alat/ teknologi sederhana yang menerapkan prinsip pesawat sederhana.

\section{Posttest}

Data hasil posttest kelas eksperimen berbasis STEM disajikan pada Gambar 6.

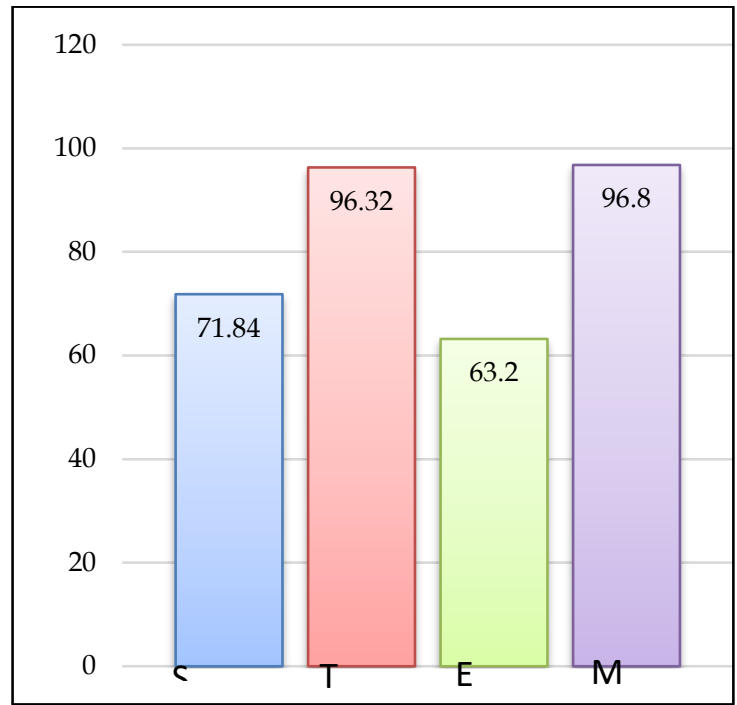

Gambar 6. Grafik Hasil Posttest Kelas Eksperimen

Gambar 6 menunjukkan persentase kemampuan STEM mahasiswa sebesar 82,04 \%. Kemampuan Science sebesar 71,84 \%, kemampuan technology sebesar 96,32 \%, kemampuan engineering sebesar 63,20 \%, dan kemampuan mathematics sebesar $96,80 \%$. Keempat kemampuan mengalami peningkatan. Kemampuan Science meningkat sebesar sebesar 27,20 \%, kemampuan technology meningkat sebesar 23,36\%, kemampuan engineering meningkat sebesar 55,20 \%, dan aspek mathematics meningkat sebesar 81,80 \%. Peningkatan kemampuan STEM menunjukkan pembelajaran STEM dapat meningkatkan keterampilan abad 21 mahasiswa. Kemampuan kritis diperoleh dari aspek science, kemampuan kreatif diperoleh dari aspek technology, kemampuan kolaboratif diperoleh dari aspek engineering, dan keterampilan komunikatif diperoleh dari kemampuan mathematics.

Data hasil posttest kelas eksperimen berbasis STEM disajikan pada Gambar 7. 


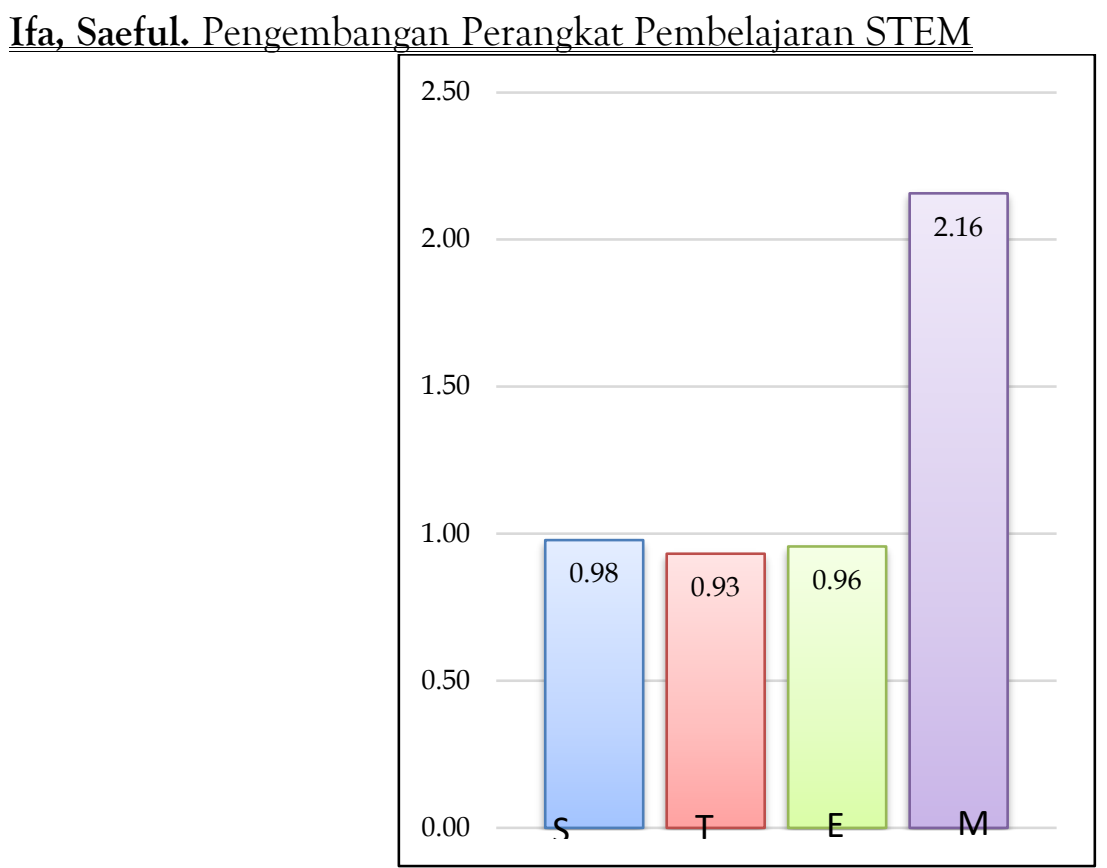

Gambar 7. Grafik Hasil Posttest Kelas Kontrol

Gambar 7 menunjukkan persentase kemampuan STEM mahasiswa kelas kontrol sebesar 2, $14 \%$. Kemampuan Science sebesar 0,98 \%, kemampuan technology sebesar 0,93\%, kemampuan engineering sebesar 0,96\%, dan kemampuan mathematics sebesar $2,16 \%$. Keempat kemampuan mengalami peningkatan dengan persentase sangat rendah. Kemampuan Science meningkat sebesar sebesar 0,56 \%, kemampuan technology meningkat sebesar 0,68\%, kemampuan engineering meningkat sebesar 0,74\%, dan kemampuan mathematics meningkat sebesar 0,91\%. Peningkatan kemampuan STEM yang tidak signifikan menunjukkan tidak ada peningkatan. Hal ini disebabkan mahasiswa kelas kontrol hanya diberi pengetahuan tentang bagan STEM, namun tidak melakukan aktivitas pembelajaran yang dapat meningkatkan kemampuan STEM dan keterampilan $\operatorname{abad} 21$.

\section{Respon Mahasiswa setelah Melaksanakan Pembelajaran Berbasis STEM}

Persentase respon mahasiswa terhadap pembelajaran sebesar $77,47 \%$ menunjukkan mahasiswa merespon dengan baik pembelajaran berbasis STEM, meskipun mereka kesulitan untuk memberikan contoh rekayasa teknologi modern yang menerapkan prinsip pesawat sederhana. Skor terendah diperoleh pada indikator ke-9 yaitu mahasiswa tidak pernah mengalihkan perhatian kepada hal-hal lain ketika pembelajaran berlangsung. 
Ifa, Saeful. Pengembangan Perangkat Pembelajaran STEM

Setelah diteliti lebih lanjut, mahasiswa masih belum fokus pada pembelajaran karena belum menyelesaikan tugas untuk mata kuliah selanjutnya. Meskipun kurang fokus saat pembelajaran, mahasiswa mengikuti pembelajaran dengan seksama. Mahasiswa dapat berdiskusi dengan teman satu kelompok dan menemukan pengetahuan baru tentang keterkaitan STEM.

\section{SIMPULAN}

Berdasarkan data hasil penelitian, maka dapat disimpulkan bahwa :

1. Penelitian pengembangan ini menghasilkan perangkat dalam bentuk Rencana Pelaksanaan Pembelajaran (RPP) berbasis STEM, Lembar Kerja Mahasiswa (LKM) berbasis STEM, bahan ajar berbasis STEM, lembar Alat Penilaian Kemampuan Mengajar (APKM) 1 dan 2, lembar observasi aktivitas mahasiswa selama pembelajaran berbasis STEM, lembar angket minat mahasiswa terhadap pembelajaran berbasis STEM.

2. Perangkat penilaian yang dikembangkan memiliki validitas sangat tinggi dengan skor 84,38 \% untuk aspek kesesuaian isi, 82,50\% untuk aspek kebahasaan, dan $82,14 \%$. untuk aspek kegrafikan.

3. Perangkat pembelajaran yang dikembangkan efektif digunakan oleh mahasiswa dan dosen pada materi pesawat sederhana karena dapat digunakan untuk mendeskripsikan profil STEM mahasiswa uji coba. Setelah melaksanakan pembelajaran berbasis STEM, kemampuan Science mahasiswa meningkat sebesar $27,20 \%$, kemampuan technology meningkat sebesar 23,36\%, kemampuan engineering meningkat sebesar 55,20\%, dan kemampuan mathematics meningkat sebesar 81,80 \%. Peningkatan kemampuan STEM menunjukkan pembelajaran STEM dapat meningkatkan keterampilan abad 21 mahasiswa. Kemampuan kritis diperoleh dari aspek science, kemampuan kreatif diperoleh dari aspek technology, kemampuan kolaboratif diperoleh dari aspek engineering, dan keterampilan komunikatif diperoleh dari kemampuan mathematics. Keefektifan pembelajaran juga ditunjukkan dengan keberhasilan dosen mendisain pembelajaran. Disain pembelajaran memperoleh skor 100 dari kedua penilai.

4. Perangkat pembelajaran yang dikembangkan praktis digunakan oleh mahasiswa dan dosen untuk materi pesawat sederhana berdasarkan respon positif mahasiswa dan 
Ifa, Saeful. Pengembangan Perangkat Pembelajaran STEM

dosen uji coba. Kepraktisan perangkat pembelajaran berbasis STEM ditunjukkan dari keterlaksanaan pembelajaran. Persentase aktivitas mahasiswa saat pembelajaran STEM sebesar 75,79 \% menunjukkan aktivitas mahasiswa saat pembelajaran termasuk kategori baik dan kemampuan mengajar dosen memperoleh skor rata-rata 97,73 .

\section{UCAPAN TERIMA KASIH}

Ucapan Terimakasih kepada: 1) Universitas PGRI Ronggolawe (UNIROW) Tuban yang telah memberikan Hibah Penetitian UNIROW dan yang telah memfasilitasi sarana prasarana dalam penelitian, 2) Prof. Dr. Supiana Dian Nurtjahyani, M. Kes. dan Ir. Hernik Pujiastuti, M. Pd sebagai validator perangkat pembelajaran berbasis STEM.

\section{DAFTAR RUJUKAN}

Arikunto, Suharsimi. (2012). Dasar-dasar Evaluasi Pendidikan. Jakarta : Bumi Aksara.. BSNP. (2010). Paradigma Pendidikan Nasional Abad XXI. Jakarta: Kemendikbud.

Bybee, Rodger W. (2013). The Case for STEM Education Challenges and Opportunities. Washington DC: NTSA Press Books.

Capraro, Mary M \& Robert M. Capraro. (2015). In-service Teachers' Implementation and Understanding of STEM Project Based Learning. Eurasia Journal of Mathematics, Science, and Technology Education, 11(1), 63-67.

Dyer, Jeffrey H.; Gregersen, Hal B., and Christensen, Clayton M. (2009). The innovator's DNA. Harvard Business Review, December 2009, pp. 1-10.

Hanover. (2011). K-12 STEM education overview. Washington DC: Connecticut, NW.

Hidayah, Ratna, Moh. Salimi, Tri Saptuti S. (2017). Critical Thinking Skill: Konsep dan Indikator Penilaian. Jurnal Taman Cendekia 1(2), 127-133.

Khoiriyah, Nailul, Abdurrahman, Ismu, Wahyudi. (2018). Implementasi Pendekatan Pembelajaran STEM untuk Meningkatkan Kemampuan Berpikir Kritis Siswa SMA pada Materi Gelombang Bunyi. JRKF UAD. 5(2): 53-62.

Ntemangwa, Celestin \& J.Steve Oliver. (2018). Implementation of Intregated STEM Instruction using Robotics in The Middle School Science Classroom. International Journal of Education in Mathematics, Science, and Technology. 6(1): 12-39.

Ostler, Elliot. (2012). $21^{\text {st }}$ Century STEM Education: A Tactical Model for Long-Range Success. International Journal of Allied Science and Technology. 2(1): 28-33.

Reeve, J. (2013). How students create motivationally supportive learning environments for themselves: The concept of agentic engagement. Journal of Educational Psychology, 105(3), 579-595. 
Ifa, Saeful. Pengembangan Perangkat Pembelajaran STEM

Sugiyono. (2010). Metode Penelitian Pendidikan Pendekatan Kuantitaif, Kualitatif, dan $R \& D$. Bandung: Alfabeta.

Thibaut, Lieve; Stijn, Ceuppens; Haydee, De Loof. (2018). Intregated STEM Education : A Systematic Review of Instructional Practices in Secondary Education. European Journal of STEM Education. 3(1): 1-12.

Trilling, B., \& Fadel, C. (2009). $21^{\text {st }}$ Century Skills: Learning for Life in Our Times. San Francisco, CA: John Wiley \& Sons.

Utami, Indri S., Rahmat, Firman S., Firmanul Catur W., Anang Suryana. (2017). Pengembangan STEM_A Berbasis Kearifan Lokal dalam Pembelajaran Fisika. Jurnal Ilmiah Pendidikan Fisika Al-BiRuNi. 6(1), 67-73.

Wang, H., Moore, T., Roehrig, G., \& Park, M. (2011). STEM integration: Teacher perceptions and practice. Journal of Pre-College Engineering Education Research, $1(2), 1-13$.

Wiggins, G., and McTighe, J. (2011). The Understanding by Design guide to creating high-quality units. Alexandria, VA: ASCD.

Winarni, Juniaty, Siti, Zubaidah, Supriyono, Koes H. (2016). STEM: Apa, Mengapa, dan Bagaimana. Prosiding Semnas Pend. IPA Pascasarjana UM, 1:976-984. 